\title{
PROFISSÃO DOCENTE NO PIAUÍ NO SÉCULO XX
}

\author{
Jane Bezerra de Sousa ${ }^{1}$ \\ Geraldo Inácio Filho ${ }^{2}$
}

\section{RESUMO}

Este trabalho tem como objetivo investigar o ser e o fazer-se professora no Piauí no século XX. Mediante a história de vida da normalista Nevinha Santos (1910 a 1999) que escreveu suas memórias em caderno de anotações e as publicou no Jornal Meio Norte, Teresina (PI), foi definido o recorte cronológico e a estrutura deste artigo, que se constitui em três fases, a primeira, de 1922 a 1928; a segunda, de 1929 a 1957; a terceira, de 1957 a 1999. A análise desses períodos possibilitou a compreensão de que, no primeiro momento, ser professor tinha significado associado a missão, vocação e sacerdócio. No segundo momento, o professor era concebido como representante da disciplina, civismo e amor à pátria, tornando-se disseminador das ideias do Estado novo. Na terceira fase, a proletarização da profissão impulsionou a formação dos sindicatos e a luta pela profissionalização, que pudesse garantir um estatuto respeitoso, melhores rendimentos e autonomia profissional. As fontes da pesquisa concentrou-se nas memórias da professora Nevinha Santos, discursos e mensagens governamentais presentes na Casa Anísio Brito, e tem como referencial teórico de análise a Nova História, ancorados em conceitos e referências de Saviani (2007), Carvalho (2007) e Queiroz (2008).

Palavras-chave: história; memória; profissão docente.

\section{PIAUÍ TEACHING PROFESSION IN THE TWENTIETH CENTURY}

\begin{abstract}
This study aims to investigate and to be a teacher in Piauí in the twentieth century. Through the life story of normalista Nevinha Santos (1910-1999) who wrote his memoirs in notebook and published in the Official Mid North, Teresina (PI) was defined clipping and chronological structure of this article, which constitutes three phases, the first, from 1922 to 1928 , the second from 1929 to 1957, the third from 1957 to 1999. The analysis of these periods allowed us to understand that, at first, were meant to be a teacher associated with the mission, vocation and priesthood. In the second phase, the teacher was seen as representative of the discipline, patriotism and love of country, becoming the state disseminator of new ideas. In the third phase, the proletarianization of the profession promoted the formation of trade unions and the struggle for professionalization, which could ensure a respectful status, higher incomes and professional autonomy. The sources of research focused on memories of the teacher Nevinha Santos, government speeches and messages present in the House Anisio Brito, and its theoretical analysis of the new history, anchored in concepts and references SAVIANI (2007), Carvalho (2007) and Queiroz (2008).
\end{abstract}

Keywords: history, memory, teaching profession.

Este artigo tem como objetivo analisar o ser e fazer-se professora no Piauí no século XX que por meio da história de vida da professora Nevinha Santos (1910-1999), (normalista que escreveu suas memórias em cadernos de anotações e as publicou no Jornal Meio Norte em Teresina) discursos educacionais e mensagens governamentais entrecruzados resultaram em três momentos distintos da profissão docente no Piauí: 1922 a 
1928 (período de formação da professora), 1929 a 1957 (período de atuação no magistério) e de 1957 a 1999 (aposentadoria e escrita de memórias). Tais momentos resultaram em concepções de ser professor no Piauí, no primeiro momento significados atribuídos à missão, vocação e sacerdócio; segundo momento, disciplina, civismo e amor a pátria e terceiro momento proletarização e luta pela profissionalização.

$\mathrm{O}$ início do século XX foi marcado, na educação do Piauí, pelas ideias disseminadas após a proclamação da república. A mensagem do governador Raimundo Artur de Vasconcelos deixou bem claro o conceito e os objetivos de educação do período:

\begin{abstract}
De quantos problemas subordinados à responsabilidade moral dos governos, e certamente a educação popular aquelle que exige, por sua complexidade e importância, a maior solicitude e devotamento. Della deriva a essência da vida, toda a aspiração do futuro, o culto do dever e do patriotismo, o espírito da civilisação, a grandeza da nacionalidade. È Também a força dos governos democráticos cuja base indestructivel, pela pureza de sua soberania comprehende o próprio povo, que será tanto mais digno e respeitável quanto mais perfeito for o seu desenvolvimento mental com a nítida intuição de seus deveres cívicos (PIAHUY, 1899, p.2).
\end{abstract}

A mensagem de 1899 indicou o rumo que norteou a educação da primeira república no Piaú, voltado para o dever e o patriotismo, o espírito de civilização e a grandeza de nacionalidade. Os deveres cívicos, a ênfase na "sciencia positiva" e a "estrada do progresso" são mencionados, o que denota os ideais positivistas que moveram os republicanos.

O Jornal O Apóstolo ${ }^{3}$, de orientação católica, publicou várias matérias relativas ao ensino e ao magistério no início do século XX, que criticaram o método mnemônico, valorizavam a ciência, desde que fosse dirigida pela religião fonte de toda moralidade, percebiam a dedicação dos professores como elemento de mudança e desenvolvimento do ensino.

Quando em todos os centros civilisados e em todos os recantos do mundo existirem mestres que se dediquem com afinco, visando só o interesse das lettras, o aperfeiçoamento do méthodo prático de ensino, então a sciencia será o patrimônio da quase totalidade dos homens $(\mathrm{O}$ MAGISTÉRIO...,1907, p.2).

A função de ser professor, que o jornal disseminou em seus artigos, era de um pintor que risca cuidadosamente uma tela. O papel do professor era de um verdadeiro lavrador, que de um campo estéril deveria transformá-lo em fértil, não esperando que as sementes atiradas ao campo crescessem por si só, mas que cuidassem destas evitando as ervas daninhas, irrigando e adubando a terra. Essa comparação da semente com a criança que o jornal apresentava como se fosse feita pelo professor, que deveria moldar a sua inteligência e o seu saber é uma ideia bem parecida com a de John Locke (1632 a 1704), para quem a mente humana é uma tabula rasa, "uma pequena tábua lisa em que nada está escrito". Muito dentro do método indutivo defendido pelos empiristas.

O professor, para igreja católica, era um prolongamento da família do pai e da mãe, um jardineiro desvelado que educava pela palavra e pelo exemplo. A maior preocupação da igreja, nesse período, era combater nas escolas as ideias iluministas, por isso, a proibição de todas as obras desse movimento. A escola leiga foi duramente atacada pelo jornal, que a considerava fora dos preceitos morais e uma guerra aos católicos. A obrigatoriedade do ensino e o não ensino do catecismo nas escolas públicas foram considerados, pela igreja católica, um verdadeiro ataque aos seus preceitos, ataques estes 
desferidos pelo diretor da instrução pública Miguel de Paiva Rosa, com o apoio do governo Anísio de Abreu, ambos balizados pela constituição brasileira, que assegurava que o Estado não deveria ministrar o ensino religioso, e se algum professor assim o fizesse e quisesse ministrar o catecismo, que não prejudicasse o seu horário de trabalho. A igreja católica reagiu duramente, chamando-os de inimigos da família, disseminadores do ódio e da injustiça.

A educação da infância e da mocidade era uma preocupação para igreja, porque deles dependiam a prosperidade do estado, a paz das famílias e a felicidade geral, é clara a disseminação e dominação da igreja católica no Piauí. Daí, a luta da igreja católica, a partir de 1910, por uma escola normal católica, porque, na concepção deles, na escola leiga:

Esse monstro é o professor leigo da escola neutra. Mal se tem feito ideia até hoje da alavanca poderosa que maneja esse simples funcionário. Não foi estudado com a devida atenção o papel que lhe cabe na formação das gerações vindouras. Agora revela-se o que é: instrumento dócil das sociedades tenebrosas, vil escravo, bestialmente ungido ao carro do governo. Esse educador art noveau, não edifica destroe. Destroe o belíssimo templo levantado por um pae extremoso, uma mãe delicada e carinhosa, a custa de esforços e fadigas sem conta. $\mathrm{O}$ anjo tutelar das crianças torna-se seu algoz (EM PRATOS LIMPOS..., 1910, p.1).

A denominação utilizada pela igreja católica aos professores das escolas leigas era de "pedagogos illuminados", e a imagem criada pelo periódico foi do professor como representante encarregado de matar as almas cristãs, incentivador das utopias de sonhos tresloucados, e as alcunhas ainda foram longe, como exemplos: "mercadores da ciência"," pedantes perversos"e "lobo voraz".

Não poupavam ainda a reforma de 1910, que previa, em seu texto, a criação dos grupos escolares, locais onde atuariam as futuras normalistas. Acusavam a escola normal de fazer com que as mulheres perdessem o perfume das virtudes cristãs substituído pela atmosfera viciada do modernismo. As normalistas eram chamadas de "bando descuidoso", que alisava os bancos das escolas normais e que pensava em ter trabalho no interior do estado, mas que não havia colocação para uma meia dúzia e seriam apenas um "acúmulo de diplomadas". "Será um verdadeiro fracasso", assim preconizavam os grupos escolares e as normalistas. As normalistas eram consideradas como as espalhadoras dos germes que matavam a alma.

$\mathrm{Na}$ realidade, essas matérias e textos publicados no jornal O Apóstolo, mantido pela Igreja Católica, faziam parte de discursos e ideias que possibilitaram amplos debates em todo o território brasileiro no campo da educação, marcado por um verdadeiro conflito ideológico.

Em contraposição a essas ideias, segundo Queiroz (2008), havia outra vertente pedagógica representada por Abdias Neves, Matias Olímpio, Luís Correia e Anísio Brito, que publicaram diversos artigos em jornais entre 1913 e 1914. Essas matérias traziam constantes discussões, principalmente sobre a questão dos métodos, que ganhavam denominações diferentes. Mas se centravam, notadamente, entre o método sintético e o método analítico.

O método sintético, que era o adotado na Escola Normal, recebeu várias críticas, e como substituto deveria ser adotado o método progressivo. Esses textos também colocavam a criança como preocupação central da educação, daí a ênfase dada à disciplina psicologia infantil ao meio escolar. Em síntese, esse grupo defendia uma educação como veículo integrador das gerações nas novas condições de um mundo em mudança, o ensino centrado na criança por meio dos métodos ativos. 
Essa ideia de modernidade e de professor moderno foi muito defendida no início do século XX no Piauí, é possível perceber isso pela revista Litericultura, no discurso de Antonino Freire, na colação de grau das primeiras normalistas, no dia 24 de janeiro de 1913, intitulado de A mulher na escola primária, que considerava uma sociedade moderna aquela que tem a mulher como preceptora, ou seja, professora de ação moralizadora e santificadora da mulher (FREIRE, 1913). Uma professora da escola moderna, essencialmente progressista e científica, em que os métodos de ensino obedecerão ao espírito humano e à busca de novos conhecimentos. Assim, ser professor, nesse momento, era designado como o "agente da novidade".

O ano de 1914 continuou a disseminar a visão de que a criança deveria ser o centro do ensino. Na mensagem do governador Miguel Rosa, de quatro de junho de 1914 ele reafirmou isto: "O melhor professor não é precisamente o que mais conhecimentos possue, é incontestavelmente aquele que melhor sabe transmitir aos discípulos os conhecimentos que possue" (PIAUHY, 1914, p.2). A arte de ensinar é vista como produto da Escola Normal, e ao professor caberia ensinar aos alunos os conhecimentos aprendidos pelo mestre, e a mulher ainda era vista como a missionária do ensino primário, por sua paciência, devendo trabalhar mais com carinho do que com rigor.

Esse pensamento iria direcionar toda ação educativa das primeiras décadas do século XX no Piauí e era ele que, de início, permeou a formação de várias normalistas, inclusive da professora Nevinha Santos. A dimensão missionária exaltava a condição de ser normalista, e assim era percebida, como lição e exemplo a ser seguido. O amor a profissão também exigia sacrifícios, uma vez que, ao ser exaltada, era digna de louvor e, para isso, deveria fazer do magistério um verdadeiro sacerdócio, ou seja, ao entrar na escola, esquecer todo o restante da sua vida e abraçar a carreira que escolhera por vocação. Assim iria completar o ideal da sociedade de uma esposa modelo, mãe exemplar e uma mestra dedicada.

O ideal de educação, já no início dos anos 1920, consolidara muitas ideias dos anticlericais e, mesmo sem ter ocorrido ainda o manifesto dos pioneiros da escola nova, o conceito de educação já estava bem dentro do que eles defendiam. Isso porque, já a partir de 1915, se iniciava a fase do entusiasmo pela educação que tinha como pensamento básico: "[...] todos os males estavam na ignorância reinante; a educação apresentava-se então como o problema principal do país, e a solução de todos os problemas sociais, políticos e econômicos estaria na disseminação da instrução" (CARVALHO, 2007, p. 34).

È possível afirmarmos isso com base na conferência de Simplício Mendes na Escola Normal, no final do ano de 1921, quando ratificou, várias vezes o sentido da educação:

É ainda disciplinar os moços na escola do desprendimento pessoal e da despreocupação do eu, diante deste motivo superior que se traduz no interesse e na felicidade coletiva [...] um homem feito aparelhado e capaz para guiar-se na vida sem outro amparo que o de si próprio (MENDES, 1921, p. 1).

Contudo, ainda nesse ano, a educação piauiense mostrava várias deficiências, como descreveu Brito (1996): a falta de preparo técnico dos professores, em sua maioria, leigos; o funcionamento irregular de muitas escolas, especialmente no interior do estado; a falta de instalações físicas, material didático e a intromissão de interesses estranhos à educação.

O ano de 1922, período em que a Professora Nevinha Santos ingressou na escola normal, ser professor primário no Piauí era uma tarefa que deveria ser desempenhada pela professora normalista, pensamento já consolidado, como vimos nos discursos anteriores. Nesse ano, o Governador João Luís Ferreira por meio do decreto 771 de setembro de 1921, 
aumentou a verba para o material escolar, restabeleceu os lugares de inspetores escolares, remodelou o conselho superior de instrução pública, proibiu a residência da professora no edifício da escola, incluiu, nos programas oficiais, estudo sobre a história piauiense e preferiu as normalistas solteiras (PIAUHY, 1922).

A escola modelo era considerada o melhor estabelecimento de instrução primária dirigido pela professora Firmina Sobreira. O governador João Luís Ferreira (1920-1924), em seus discursos apontou o magistério primário como o verdadeiro lugar para a mulher, porque esta era a maior responsável pela infância, e esse foi um pensamento que permeou toda a política educacional do seu governo, ou seja, o magistério primário como locação de trabalho para as normalistas.

Esse período era o momento áureo das normalistas, primeiro, por seu espaço profissional consolidado, e, segundo, com a construção dos grupos escolares, que começaram a se espalhar pelo Piauí inteiro. A profissão tinha um status social, tanto que todas as festas, exames, notas, colações de grau eram motivos de destaques na imprensa local. Até um prédio majestoso foi construído para abrigar a Escola Normal e, ao mesmo tempo, demonstrar a sua importância perante a sociedade piauiense. Essas mudanças representavam o pensamento novo, pelo qual o investimento na educação popular e a erradicação do analfabetismo, projetos dos republicanos, salvariam o país da ignorância, e os missionários desse pensamento seriam as professoras normalistas.

Com todas as atenções dos governantes e da sociedade voltadas para a Escola Normal, o discurso do Professor Higino Cunha como paraninfo da turma de 1922, publicado em 1923, intitulado O Ensino Normal no Piauhy, fez uma retrospectiva da fundação da instituição e da luta pela implantação do ensino normal no Piauí. Mostrou ainda que o combate ao analfabetismo estava na sua fase definitiva devido à ação eficaz e permanente da união, dos estados, dos municípios e dos particulares.

$\mathrm{O}$ discurso do professor Higino Cunha foi um dos poucos que mostrou que a profissão docente, mesmo com reconhecimento social, era mal remunerada e mal assistida pelos governos em razão da baixa remuneração, falta de valorização, falta da qualidade do ensino, de instalações e equipamentos adequados. Essa fala representou uma defesa às professoras que, muitas vezes, se silenciavam por não conseguirem o enfrentamento com o poder hegemônico, já que o ingresso na carreira e as promoções de então eram efetivados como mecanismos de controle.

Conceber a profissão como extensão do lar e da maternidade fazia parte dos discursos das normalistas que, em nome do melhor para todos e na realização pessoal de serem professoras, silenciaram a luta por melhores condições de trabalho e se envolveram nas redes do poder evitando dessa forma, as perseguições políticas.

Todo esse direcionamento influenciou na formação de uma geração de professoras normalistas, fato evidenciado nas memórias de Nevinha, quando revelou: 'Sentia-me como mãe, pois professora é quase ser mãe! Amei ensinar. Adorei a minha profissão e me sentia muito feliz naquela sala de aula" (SANTOS, 1997b, p.2).

No discurso do diretor da instrução pública no Piauí, Christino Castelo Branco, como paraninfo na colação de grau, que ocorreu no dia 14 de janeiro de 1928, é possível perceber os objetivos da formação da normalista, uma vez que, o método intuitivo era apontado como o apropriado, alunos e professores com formação cívica e a mulher com papéis sociais definidos, de ser mãe e professora.A palmatória era considerada algo atrasado, por isso elogiava-se o método de ensino intuitivo, caminho metódico para a 
educação dos sentidos e para educação pelas coisas e pela experiência. Esse método de ensino popularizou-se sob a denominação de lições de coisas e método objetivo.

Para a consecução desses objetivos, era crucial o trabalho do magistério, única carreira aberta ao sexo feminino, sendo a profissão docente concebida como sacerdócio, cuja vocação era afeita à mulher, mais bem preparada para desempenhá-la. Assim, o magistério ganhou o caráter de missão e vocação, configurando-se como continuidade do trabalho do lar. Nesse processo, a mulher deveria viver em sociedade e ser agradável ao homem, mas não concorrer com ele profissionalmente, pois isso ultrapassaria os limites da segurança social.

Para Queiroz (2008), no período de 1880 a 1930, as mudanças em relação à educação foram: a incorporação das normalistas na rede oficial de ensino na capital e no interior, substituindo os professores interinos e leigos; a construção de prédios escolares e a feminização do magistério.

Como vimos até aqui, os discursos da imprensa podem ajudar a entender como era percebido o "ser professora primária no Piauí" no início da república, ainda uma profissão muito desvalorizada, mas os projetos republicanos de progresso, por meio da educação popular, modificaram esse quadro. A abertura das escolas normais gerou debates de ideais educacionais entre católicos e anticlericais; estes últimos defendiam um pensamento mais próximo do escolanovismo. Após esses debates, foi possível percebermos a institucionalização da profissão professora normalista como missionária, mãe e salvadora da pátria, além de estar coberta de reconhecimento social e uma áurea gloriosa, o que escondia por vezes, a falta de reconhecimento econômico e as péssimas condições de trabalho assumidas, sobretudo, dentro do interior do estado.

A professora Nevinha ingressou na escola normal, em 1922, no período em que estava consolidado o papel da mulher dentro do magistério primário, e as normalistas representavam motivo de orgulho do estado e da sociedade, por serem como apóstolos, no sentido de difundir a instrução onde quer que fosse, nem que, para isso, houvesse sacrifício pessoal. Ao término de sua formação em 1928, o método intuitivo já era o escolhido como o melhor para educação das crianças piauienses, essas como centro do ensino e a professora como desempenhadora também de outros papéis, de mulher e de mãe. Pensamentos e ideias que foram a base de toda uma prática nos grupos escolares piauienses, como veremos no capítulo seguinte.

Matias Olympio, em sua mensagem de 01 de junho de 1928, orientava a intensificação dos estudos na formação dos futuros professores no sentido de que o ensino primário não se limitasse as questões teóricas e que fosse mais proveitoso. Objetivo que poderia ser obtido por meio de um programa de ensino que aliasse teoria e prática com a finalidade máxima de ensinar a escrever e ensinar a ensinar (PIAUÍ, 1928)

O ano de 1929 foi marcado pelo desbravamento das professoras normalistas pelo interior, o que gerou uma preocupação por parte do estado, já que muitas vezes, as professoras não encontravam as condições necessárias de trabalho e nem tampouco um salário que compensasse o esforço do afastamento da família. A justificativa do estado da falta de melhoramento dessa situação, a escassez dos recursos financeiros. O que podemos refletir sobre essa conjuntura, era que a motivação das professoras, em enfrentar todas as dificuldades, originava-se dos ideais inculcados de missão, vocação e salvação (do analfabetismo), durante a formação delas na escola normal.

A revolução de 1930 e o governo do país nas mãos de Getúlio Vargas mudaram os rumos da educação no país e no estado. Saviani (2007, p.193) conclui que a revolução de 1930 foi um "estado de compromisso" um agente da burguesia industrial. Após a posse do governo, em 1930, foi criado o IDORT (Instituto de Organização Racional do Trabalho), 
que exerceu forte influência sobre as políticas governamentais em todo o período pósrevolução de 1930, que se estendeu até 1945, marcando a reorganização educacional do país. A criação no Ministério da Educação e Saúde pública, em novembro de 1930, a Reforma Francisco Campos, em 1931, mostraram que o novo governo tratava a educação como uma questão nacional, "convertendo-se, portanto, em objeto de regulamentação, nos seus diversos níveis e modalidades, por parte do governo central" (SAVIANI, 2007, p.196).

O capitão Landry Sales Gonçalves (1931-1935), mesmo com suas mensagens meramente técnicas, sem muitas menções à formação de professores e as deficiências do ensino, custeou, nesse período, um curso em Minas Gerais para aperfeiçoamento de professores. Foi possível analisar a educação e a profissão docente nessa ocasião pelo relatório do diretor da instrução pública em 1932, Martins Napoleão, que mostrou sérias preocupações com a educação do Piauí. A questão curricular, que deveria ser modificada, voltada para a participação da vida sócia, e ao mesmo tempo, produtiva. O ensino primário deveria ser prático e concreto, estimulando o interesse infantil, tendo com centro principal do ensino o aluno, com vistas a obter o desenvolvimento da observação e do raciocínio "dever-se-ão, no ensino primário adotar as conquistas positivas da escola nova" (PIAUHY, 1932, p.2).

As orientações para os professores eram de utilizarem lições variadas, concisas, vividas, deixando ao educando a iniciativa de buscar conhecimentos. Ser professor para Martins Napoleão era um:

Guia esclarecido e metódico, investigador da feição moral do aluno, não só indagando dos pais ou responsáveis quais as suas tendências e hábitos como também observando a criança na classe, no recreio entrada e saída e ainda em suas mútuas relações (PIAUHY, 1932, p.2).

Notamos os ideais escolanovistas como direcionadores das práticas educacionais nesse período, embora não houvesse, ainda, a publicação do manifesto dos pioneiros da escola nova, as ideias já estavam em franca expansão. Isso também se deu em virtude do Diretor da Instrução Pública, Martins Napoleão, ter participado da IV Conferência Nacional de Educação, ${ }^{4}$ no Rio de janeiro, no período de 13 a 20 de dezembro de 1931.

A preocupação com a formação do professorado nesse sentido era imensa, como resultado, um professor que catalisasse as lições para o interesse coletivo dos alunos. Além disso, a formação do sentimento cívico era aconselhada para por em evidencia a organização política do Brasil e do Piauí e dos seus municípios, com o objetivo de despertar nos alunos o exercício dos seus direitos e deveres, para tanto, era necessário o estudo da história pátria e dos heróis, a fim de exaltar o amor à raça. Essas lições deveriam ser aproveitadas nas oportunidades da convivência família, escola e sociedade.

Outra questão nova seria o estímulo à educação física ${ }^{5}$ para auxiliar e regular o desenvolvimento do corpo. As atividades de Educação física se restringiriam ao cultivo da voz, conselhos higiênicos, defesa individual, conservação da saúde, exercícios calistênicos e jogos recreativos.

Medidas de infraestrutura educacionais, como, por exemplo, a construção de prédios escolares adequados aos grupos escolares, planejados pelo engenheiro Luís Mendes Ribeiro Gonçalves. Os prédios eram construídos conforme os objetivos do grupo escolar, ou seja, iluminação e, em sua maioria incrustado bem no centro das cidades, ou em locais de maior importância, denotando uma medida majestosa e fruto de um ensino organizado.

$\mathrm{O}$ aparelhamento das escolas primárias, fornecimento de material didático e mobiliário adequado foram uma constante. O Grupo Escolar Coelho Rodrigues recebeu em 
1932 o valor de 16:000\$000, e, em 1933, a inauguração de sua sede própria. Nesse mesmo ano, no Piauí, foi colocado em funcionamento o regulamento de 1933, que dentre outras mudanças, tinha forte influência do manifesto dos pioneiros da escola nova em 1932.

A partir de 1935, com a indicação de Leônidas Melo ao poder, governo que exerceu o poder, até o fim do Estado Novo, houve maior preocupação com a delineação do ser professor nesse momento, a nosso ver, como instrumentos de inculcação das ideias do período Getulista. Foi possível essa conclusão por meio de análises das mensagens governamentais, matérias de jornais, festas cívicas realizadas e também depoimentos de ex-alunos.

Durante todo o governo de Leônidas Melo, a educação esteve nas páginas do diário oficial, ou presente nos seus discursos e mensagens. Fotografias e grandes concentrações das escolas e, respectivamente, de seus estudantes nas imensas e várias paradas cívicas. Num claro interesse de demonstração de grandiosidade do governo e de seus representantes, Getúlio, como presidente do Brasil e Leônidas Melo, como interventor do Piauí. Esses eventos serviam para personificar os mitos e acentuar as qualidades do chefe da nação, da escala maior para as menores, assim como informa Carone (1988, p. 166), "Em cadeia, tenta-se mostrar como todos os líderes que se identificam com o Estado Novo apresentam traços e personalidades ímpares, que os distinguem dos outros, apesar de não atingirem o nível e as qualidades do chefe da nação".

Na mensagem de Leônidas Melo, é possível compreendermos todo o pensamento que nortearia a educação no Piauí e a concepção da profissão docente para o poder público e o discurso abaixo reflete as diretrizes que se seguiram nos anos posteriores.

A aura de glória que cobriu o magistério primário no Piauí, no início do século XX, começava a falir durante o período getulista, o próprio governo reconheceu a desvalorização docente verificada pelos baixos salários e as condições péssimas de trabalho. E ainda apontou o surgimento de doenças como a neurastenia adquirida pela profissão. Inclusive a própria normalista começava a perder o entusiasmo pela educação no interior.

Foi em nome de todo esse quadro da profissão docente que o governo do Piauí tomou providências como exemplo de colocar uma gratificação de 30 por cento no segundo turno, considerado muito pouco pelas professoras da época. Em contraposição, foi criado o quadro de professoras substitutas, que aceitavam trabalhar mais barato e sem ter os mesmos direitos que as do quadro efetivo.

O ano de 1936 foi caracterizado por muitas mudanças na educação: a instalação do cinema educativo $^{6}$; participação de cursos em Belo Horizonte para as professoras; o festival escolar (comemoração da conclusão do ensino primário); a semana da pátria; a semana da criança (alunos até seis anos); o gabinete dentário escolar; as diversas paradas cívicas; o clube de leitura Firmina Sobreira e a Liga a Escola Nova, estes últimos fundados na Escola Normal em Teresina.

A atribuição à revolução de 1930 como transformação dos homens e na educação, embora com o enfrentamento e evidencia de tantos problemas, ainda era presente nos discursos da imprensa local:

A Revolução de 1930 operou o milagre de transformar a mentalidade dos homens públicos do Brasil que se empenham agora corajosamente pelo problema máximo da nacionalidade - instrução e educação. Hoje, os grupos escolares, as escolas agrupadas, existem em diversos municípios do Estado, construídos de acordo com as mais rigorosas exigências pedagógicas, providos de sufficiente material escolar e servidos por intelligentes e dedicadas normalistas que levam patrioticamente ao 
longínquo sertão piauiense as luzes das letras do alphabeto (GONÇALVES, 1936, p.4).

A instalação do Estado Novo manteve, no Piauí, o mesmo interventor, Leônidas Melo, e a preocupação, a partir da implantação do novo modelo, concentrou-se na imagem do governo e seus representantes. Uma delas, acabar a velha mentalidade que sobrepunha as preocupações da politicagem ao interesse público. $\mathrm{Na}$ educação, o civismo e a verdadeira exaltação ao presidente da república e governador do estado eram uma constante. O professor atuaria como transmissor de conhecimentos para a formação da criança e da mocidade voltados para o engrandecimento da pátria. A criança, vista como esperança do futuro. $\mathrm{O}$ estudo e o trabalho, como impulsionadores do crescimento da pátria. E, acima de tudo, a reafirmação do Estado Novo como um Brasil grande, forte, unido, disciplinado e civilizado. E o educador, a serviço desse pensamento.

Por outro lado, houve, ainda, um grande empenho por parte do governo em expandir o ensino primário no Piauí, tendo recebido o Estado destaque em virtude do aumento de matrículas em 215 por cento, no período de 1933 a 1937. Ocorreu, inclusive, o investimento nos cursos especiais de educação física, que funcionaram com regularidade a partir de 1939.

Em 1942, o serviço de Inquéritos e Pesquisas Pedagógicas foi instalado no Piauí, vinculado ao INEP, e tinha como objetivos: amparar alunos pobres, fazer propaganda do ensino, despertar o amor a pátria, entreter a cooperação da família. Outras medidas também foram tomadas como: bolsas para os cursos de educação física. Esse serviço transformou professores e alunos em estatísticas, muitas, positivas para o governo.

Em 1945, a queda do Estado Novo trouxe ao Piauí três interventores federais até que, em 1947, proporcionou a ascensão ao poder à UDN. Assumiu, nesse momento, o governo José da Rocha Furtado (1945 a 1951), ${ }^{7}$ que sempre alegou em suas mensagens, a falta de dinheiro para investimento na educação e reclamava do número de professoras leigas presentes ainda na escola.

O desequilíbrio orçamentário sempre foi o motivo para que o governo Rocha Furtado, não investisse na instrução pública como também na mobilização dos inspetores de ensino. Os discursos desse período sempre denunciaram o descaso com a educação. $\mathrm{O}$ professor Epifânio Carvalho apontou as causas para o descaso com a educação: reformas apressadas, falta de escolas e de professores com grande experiência e força de vontade a enfrentar o sertão com alunos subnutridos. Mostrou, ainda, que somente o professor poderia modificar essa situação, no sentido de levar a sabedoria e a harmonia aos povos (CARVALHO, 1948).

A conclamação ao professor como solução do problema da educação era uma medida do estado, que alegava falta de condições de investimento na educação e, em decorrência, requisitava o empenho dos professores para se manterem na sala de aula. $\mathrm{O}$ governador José Rocha Furtado alegou: "deve-se o rendimento delas (professoras) a dedicação das abnegadas professoras primárias que exercem o magistério em condições que não lhes proporcionam nenhum estímulo" (PIAUÍ, 1950, p.12). No seu discurso, em 1950, corroborou esse pensamento e elogiou o professorado por continuar exercendo a profissão mesmo com tantas dificuldades:

Professorado primário do estado comprovou o seu zelo e devotamento a profissão sem embargo nas dificuldades que a já citada escassez de recursos the criou no exercício da relevante função (PIAUÍ, 1950, p. 12).

Percebemos que toda ideia de devotamento a profissão professor, sacrifício e vocação ainda continuaram, e com um resultado negativo para a identidade docente no 
sentido de aceitar a desatenção e a falta de investimento na educação por parte do estado. Ou seja, a missão e a vocação são conclamadas, dessa forma, o professor era consagrado ao renunciar seus direitos individuais em nome do coletivo, um ser abnegado a serviço da humanidade. Conforme Carvalho (2007), as reformas educacionais implementadas durante o período republicano falharam em suas tarefas de revigorar o ensino no País. Falharam por não terem sido criativas, não terem produzido modelos de educação para uma sociedade em transformação, que desejava alcançar o estado de povo civilizado.

A revolução de 1930 trouxe aos professores piauienses uma melhora nos prédios educacionais e o incentivo do professorado a se deslocar para o interior. $\mathrm{O}$ investimento foi intenso. O Estado Novo, representado por Getúlio Vargas e Leônidas Melo no Piauí, inculcou o ser professor no representante da disciplina, com civismo e defensor de uma pátria grande e unida, isso refletido no cotidiano escolar, do início da aula às paradas cívicas. A educação era o grande foco dos investimentos e das notícias em jornais, consequentemente o professor como disseminador das ideias que moviam o Estado Novo.

O período posterior à queda do Estado Novo mostrou uma educação sem aplicação de recursos financeiros, professores mal remunerados e a consolidação da desvalorização da profissão docente. $\mathrm{O}$ estado se apegou às velhas ideias de abnegação e amor à profissão para manterem, nas salas de aula de condições péssimas, os professores, esses como solucionadores de todo o problema na visão do estado e seus governantes.

O terceiro momento, de 1957 a 1999, foi o período em que a professora Nevinha Santos aposentou-se, quando então se surpreendeu com a maneira de ser professor no Piauí, situação flagrante no salário que recebia como aposentada e nas greves dos anos 1990. Esse quadro educacional com que deparou se delineou nos anos de 1960 do século XX, marcado pelas discussões da LDB 4024/61 e pelas transformações ocorridas com o salário-educação mantido pelo FNDE, a implantação do PABAEE e a Constituição de 1967, a qual estendeu para oito anos a gratuidade e a obrigatoriedade do ensino, aumentando o tempo de escolaridade e retirando a vinculação constitucional dos recursos. Essa conta teria que ser paga por alguém - o corpo docente.

A expansão da escola pública ocorreu desordenadamente, aumentando-se o número de prédios e contratando-se professores em sua maioria sem concursos e sem consciência da luta, o que resultou num processo intenso e acelerado da proletarização da profissão, em contraposição à profissionalização tão almejada. Nesse contexto, em 1968, é criada a APEMOP, primeira iniciativa de organização sindical dos professores estaduais.

Nos anos de 1970 houve amplos debates a respeito da LDB 5692/71, investimentos educacionais do convênio MEC/BIRD/ESTADO e o estatuto do magistério. No final dessa década, os números mostravam o processo de retraimento do ensino de $2^{\circ}$ grau tanto na capital como no interior. A falta de recursos provocou a desaceleração do processo educativo, a carência de pessoal com qualificação e a saída da classe média da escola.

Nos anos de 1980, em relação à valorização do magistério, foi consolidado o projeto Logos II, ocorrendo ainda debates acerca das mudanças contidas na nova Constituição e ainda discussões sobre a nova lei da educação, aprovada oito anos mais tarde. O quadro educacional piauiense, por sua vez, estava caracterizado, por uma má utilização da jornada escolar, ensino multisseriado na zona rural, metodologias inadequadas, autoritarismo na relação professor-aluno, falta de compromisso com o ensino público, deficiência na avaliação de ensino-aprendizagem, inadequação dos currículos à cultura local, má remuneração e falta de qualificação dos professores.

Em 1990, os alunos do Piauí perderam o ano letivo, em virtude da ocorrência da maior greve na história do estado, no período de agosto de 1990 a abril de 1991, sendo que, com isso, o sindicato dos professores se fortaleceu. 
Ser professor representava ganhar pouco, não pagar as contas em dia, ter baixa autoestima, salários atrasados e participar de greves. Toda essa situação causou surpresas à professora Nevinha e foi tema de sua escrita. Seu espanto se respaldou no fato de sua formação como normalista ser considerada como unificadora de saberes e difusora de uma metodologia moderna a substituir um quadro de professores mestres-escola, leigos, assistemáticos, incipientes e mal pagos. Além disso, havia o glamour associado à normalista, embora as condições de trabalho e os salários não fossem condizentes, tendo a profissão grande reconhecimento social.

O final do século XX trouxe prenúncios de que o início do século XXI, com a LDB 9394/96 e o fortalecimento do sindicato dos professores estaduais, haveria uma maior valorização do professor pelo menos no sentido de garantir salários pagos no vencimento, gestão democrática, planos de cargos e salários, conservação das escolas e a garantia da profissionalização através de um estatuto e rendimentos respeitosos que levassem à conquista da autonomia da profissão.

Nevinha Santos faleceu em 1999, sem ver a utopia de uma profissão docente valorizada pelo Estado do Piauí e, embora tenha assistido à proletarização dos profissionais de educação, até o final dos seus dias, orgulhava-se de ser professora. Sua história oferece uma oportunidade de se repensar a profissão docente, não adotando um discurso de vitimização, segundo o qual o professor é sempre vítima, mas entendendo que o dialogo com o professores e a compreensão de que eles são os sujeitos de seu fazer deve contribuir para um compartilhar de experiências, buscando-se assim elevar o grau de valorização desses profissionais.

\section{Referencias}

BRITO, Itamar Sousa. História da Educação no Piauí. Teresina: UFPI, 1996.

CARONE, Edgar. O Estado Novo (1937-1945). São Paulo: Difel, 1977.

CARVALHO, Carlos Henrique. República e Imprensa: as influências do Positivismo na concepção de educação do professor Honório Guimarães; Uberabinha, 1905-1922. 2ed.Uberlândia: Edufu, 2007.

CARVALHO, Epifânio. Escola Normal Antonino Freire. O Piauí, n.422, Teresina, PI, 16 dez.1948.

EM PRATOS Limpos, O Apóstolo, Teresina, PI, 03 jul.1910, p.1.

GONÇALVES, Maria Cacilda Ribeiro Gonçalves. Educação Nacional. Diário Official, Teresina, PI, n 131, 12 jun.1936.p.4.

FREIRE, Antonino. A mulher na escola primária. In: NEVES, Abdias (org.). Litericultura. Teresina: Imprensa Oficial, 1913.

MENDES, Simplício. O problema da educação nacional. O Piauhy, n.526, Theresina, 24 nov.1921, p.1.

O MAGISTÉRIO, O Apóstolo, Teresina, 30 jun.1907, p.2. 
PIAUHY, Governador, 1896-1900 (Raimundo Artur de Vasconcelos) Mensagem apresentada à Câmara legislativa, pelo Exmo. Sr.Governador do Estado, em 1899. Theresina: Piauhy, 1899.

PIAUHY, Governador, 1912-1916 (Miguel de Paiva Rosa) Mensagem apresentada à Câmara legislativa, pelo Exmo. Sr.Governador do Estado, em 04 de junho de 1914. Theresina: Typ. Paz, 1914.p.2.

PIAUHY, Governador, 1920-1924 (João Luiz Ferreira) Mensagem apresentada à Câmara legislativa, pelo Exmo. Sr.Governador do Estado, em 01 de junho de 1922. Theresina: Typ. O Piauhy,1922.

PIAUHY, Governador, 1925-1928 (Matyas Olympio de Melo) Mensagem apresentada à Câmara legislativa, pelo Exmo. Sr.Governador do Estado, em 01 de junho de 1928. Theresina, Piauhy, 1928.

PIAUHY, Diretoria da Instrução Pública. Relatório da Instrução Pública apresentado pelo director Martins Napoleão em 1932. Teresina, Caixa da instrução Pública, n.1, Arquivo Público do Estado do Piauí, 1932.p.2. [manuscrito]

PIAUHY, Governador, 1947-1951 (José da Rocha Furtado) Mensagem apresentada à Câmara legislativa, pelo Exmo. Sr.Governador do Estado, em 01 de junho de 1950. Theresina: Imprensa Oficial, 1950.

QUEIROZ, Teresinha. Educação no Piauí: (1889-1930). Teresina: Ètica, 2008.

SANTOS, Nevinha. Adorei e me sentia muito feliz em ser professora. Jornal Meio Norte, n. 1024, Teresina, 22 out.1997b. p.3. (Caderno Alternativo).

SAVIANI, Demerval. História das Ideias Pedagógicas no Brasil. Campinas: Autores Associados, 2007.

Recebido em janeiro-13

Aprovado em maio-13

\section{Notas}

1 Doutora em Educação. Professora Adjunta Universidade Federal do Piauí. Membro do NESC. jane bezerrasousa@yahoo.com.br

${ }^{2}$ Professor Associado IV da Faced/PPGED da Universidade Federal de Uberlândia, membro do NEPHE, geraldoinacio@terra.com.br.

${ }^{3}$ O jornal pertencia a Igreja Católica, órgão em que eram publicadas diversas matérias contra a maçonaria. Para Tavares (2003), essa luta entre os maçons e a igreja se arrastou no Piauí por mais de dez anos, e se agravou em 1909, com a transferência do bispo Dom Joaquim de Almeida para a Diocese de Natal. Em 1911, a igreja mobilizou homens armados contra o poder civil, em função da eleição dos mais radicais dos maçons Miguel Rosa, como reação a isso, o novo governador ordenou que o jornal o Apóstolo fosse empastelado, o que arrefeceu essa luta. 
${ }^{4}$ A IV Conferência Nacional de Educação foi realizada no rio de janeiro em 1931, para tratar do tema "As grandes diretrizes da educação popular", oportunidade em que nasceu o Manifesto dos Pioneiros da Escola Nova (1932), que reclamavam reformas educacionais, com um plano nacional e contínuo. Defendiam a educação das massas rurais e do elemento trabalhador nas cidades, servindo de orientação para as políticas educacionais no governo Getulista.

${ }^{5}$ A educação física também tinha um tríplice papel na educação, física, intelectual e moral. É importante para o homem em virtude da busca de um homem feliz com suas faculdades físicas e desempenhando o seu papel social.

${ }^{6}$ Em 1935, o governo Leônidas Melo firmou contrato com o Instituto do cinema educativo, que fornecia mensalmente oito filmes, especialmente instrutivos, exibidos no teatro 4 de setembro para as crianças e professores dos grupos escolares.

${ }^{7}$ O governo Rocha Furtado foi um dos mais tumultuados no Piauí enfrentou resistências internas do seu próprio partido, a UDN, e externas, do PSD, partido em que se encontravam seus adversários, sendo maioria na assembleia legislativa. As dificuldades do governo cresceram com a Constituição de 1947, que previa uma serie de vantagens, benefícios e privilégios que levaram a uma desorganização administrativa e ao atraso de salários de oito meses para algumas categorias profissionais, além de uma crise financeira marcada pelo declínio no mercado internacional da cera da carnaúba. 